Books Are Being Read, published as a UCLA Library Occasional Paper, reports the "summary results" of this study. The report is, indeed, summary-so summary, in fact, that it is difficult to see how the findings could have been very useful in library planning. The results of the questionnaire, presented in eight pages and interpreted in three more, are necessarily generalized. Sometimes they are confusing. For example, it is explained that the number of books borrowed was coded in units between one and nine, and in tens between ten and one hundred. Then it is stated that "... the pattern for assigned reading shows that the most usual amount borrowed was from 10 to 19 books, the next most usual is one book, and the third most usual is 20 to 29 ," without any notation of the number of students represented in any of these "most usual" categories. The "most usual" amount of pleasure reading from the university libraries is reported as two books. And yet, in another place it is noted that "... pleasure reading fell far behind, well over half the sample canvassed reporting no books borrowed for this purpose in the course of this semester." The final question asked the student to comment briefly on the UCLA Library. These comments were classified by topic, and seventeen pages of pro and con samples for each topic are presented in the appendix. Again it is hard to see how comments such as "I appreciate the ease with which I can get almost any book I want to read" and "It takes too long to get the books and after waiting they're usually not in" can be of much help in planning library facilities or services. But, with original phrasing and spelling carefully preserved, some of the comments are delightful. My favorite is this: "Quite reading rooms should be quite."

The somewhat defensive title of the paper is perhaps justified by some indication of a bit more pleasure reading than reported in earlier studies of this type. The evidence here, too, however, is very limited. In short, this report is neither full enough to provide a clear picture of UCLA students' reading and their use of the library, nor is it precise enough to serve as a helpful example of research methodology.-Patricia B. Knapp, Monteith College, Wayne State University.

\section{History of Microfilm}

Microfilm: A History, 1839-1900. By Frederic Luther. Annapolis, Md.: The National Microfilm Association, [ ${ }_{[} 1959$ ] $195 \mathrm{p}$. illus. $\$ 7.50$.

The theme for the April meeting of the National Microfilm Association in Washington was: "A Centennial of Progress." There were papers on the historical aspects of the craft and two displays in the exhibit were on the history of microphotography. Frederic Luther, the vice president of the association, pulled together the results of about twenty-five years of study on the early years of the art so that his book could be published in connection with this meeting.

The greater part of this book deals with the activities of two men: John Benjamin Dancer (1812-1887) of England and René Prudent Dagron (1819-1900) of France. Dancer was a scientist, inventor, and optical manufacturer of Liverpool and Manchester. In 1839, as soon as he learned about the process, he began to manufacture daguerreotype cameras for which he offered processing service. That same year he made a daguerreotype microphotograph at a reduction ratio of $160: 1$. When we remember what a stir Eastman Kodak caused less than five years ago with their Minicard made at 60:1, we can fully appreciate Dancer's first venture into microrecording. After 1851, with the advent of the wet-collodion process, he experimented with microphotographs made on this more suitable medium. Though he solved many of the basic problems and produced creditable images, he did not go further than preliminary experiments with the process.

Dagron, however, brought the art out of the laboratory and into the market place. On June 12, 1859, he received the first microfilm patent, and in thirty months he was doing a business in microphotographic novelties that required a staff of 150 workmen. None of the independent microfilm service agencies today can boast such a number of employees. In 1870-71 he flew out of besieged Paris in a balloon and set up the famous pigeon-post airmail microfilm service in Tours. Mr. Luther's account of the balloon trip is as exciting as Carlyle's 
description of Marie Antoinette's flight to Varennes, and has the advantage of a happy ending. In 1873 Dagron patented a microfilm viewer designed for use by the French Army for microphotographic maps, and he was active in the field till after 1889 when he exhibited in the Paris World's Fair.

Appended to accounts of the work of Dancer, Dagron, and other nineteenth century microphotographers, are translations of Dagron's two principal publications and an account of the balloon service during the siege of Paris. There are biographical notes on many persons connected with the art and a chronology of microfilm developments. This book is being published in an edition of 500 printed copies and will be kept permanently in print in microfilm and micropaper. The complete bibliography of sources consulted is not included in the printed version, but will be given in the microformat editions.-Hubbard W. Ballou, Photographic Services, Columbia University Libraries.

\section{Library Resources in the}

\section{Southeast}

The Humanities, the Sciences, and the Library in the Southeast: Proceedings of the First Southern College and Research Library Workshop, June 26, 1958. Tallahassee: Florida State University Library School, 1958. 67p. \$1.00. Paper.

The first Southern College and Research Library Workshop, sponsored by the Library School of the Florida State University in the summer of 1958, provided scholars and librarians with the opportunity to consider and to discuss the library resources available for research in the South, or more specifically the Southeast. With the publication of The Humanities, the Sciences, and the Library in the Southeast, the papers presented at this workshop are now available in an attractive format.

Eight of the papers presented at the workshop are included in the proceedings here under review. In the keynote address, "Research, Resources, and Librarianship in the
Southeast," Benjamin E. Powell, Duke University librarian, presents with skill and understanding the background against which the strengths and weaknesses of the region's libraries may be viewed. The four papers which follow Dr. Powell's describe and comment upon in some detail trends and directions in research in the humanities and the sciences. Dr. Sarah Herndon of the Florida State University English faculty and Dean Werner A. Baum of the FSU Graduate School, representing respectively the humanities and the sciences, present the scholar's view of Southeastern libraries, their resources and their problems. W. Stanley Hoole, University of Alabama librarian, and Dorothy M. Crosland, Georgia Institute of Technology director of libraries, describe some of the difficulties librarians face in attempting to meet the needs of scholars once they have been determined. Willard O. Mishoff, formerly specialist for college and research libraries in the United States Office of Education and now librarian of the Mississippi State College for Women; Robert B. Downs, dean of library administration, University of Illinois; and Graham Roberts, library consultant, Southern Regional Education Board, consider in their papers the resources of Southeastern libraries and the program of and plans for interlibrary cooperation in the region.

Librarians from nine Southeastern states (Alabama, Florida, Georgia, Kentucky, Mississippi, North Carolina, South Carolina, Tennessee, Virginia) reported on the research collections available in the libraries of their respective states. Their reports are published as an appendix to the workshop proceedings, and they should prove useful to scholar and librarian alike.

While much remains to be done to strengthen Southeastern libraries, even a cursory reading of these papers and reports will reveal that great progress has been made and that there are distinguished library collections in the South.

The committee which planned the workshop is to be commended highly for its selection of speakers and discussants. The papers here published are both informative and well written._John David Marshall, University of Georgia Library. 